\title{
The Corporation: A circular process of value creation
}

\author{
Miguel Goede \\ University of Governance, Curacao
}

\begin{abstract}
Corporate governance is not new. It reached new heights in the 1980 s when corporations became dominant in the era of neoliberalism. Corporate governance is about the way power is exercised over corporate entities. It covers the activities of the board and its relationships with the stakeholders or members, and with those managing the enterprise, as well as the external auditors, regulators and other legitimate stakeholders. Good corporate governance is an attempt to make corporations behave more ethically. The corporation is driven by short term profit. Good governance is governing according to the following principles: Honesty, Transparency, Accountability, Responsiveness, Independence, and Fairness. A more circular perspective on corporate governance might result in a more ethical corporation.
\end{abstract}

Keywords: Good Corporate Governance, Corporate Governance Cycle, Circular

\section{INTRODUCTION}

The term "corporate governance" is relatively new (1980s) but the concept is old. Some attribute it to English writer Geoffrey Chaucer (c. 1343 - 1400) [1]. Others attribute it to Adam Smith in his Wealth of Nations:

"Nothing can be more completely foolish than to expect the clerks of a great counting-house at ten thousand miles distance, and consequently almost out of sight, should upon a simple order from the masters, give up at once any sort of business on their own account, abandon forever all hopes of making a fortune, of which they have the means in their hands, and content themselves with the moderate salaries which those masters allow them, and which moderate as they are, can seldom be augmented, being commonly as large as the real profits of the company trade can afford." (WN IV.vii.c.105: 638-9) [2].

In the above quote Adam Smith formulated the principal / agent dilemma that is the core issue that corporate governance addresses. This theme will be developed in this chapter.

The first corporations were the Dutch and British entities created to exploit the colonies in the $15^{\text {th }}$ and $16^{\text {th }}$ centuries [3]. Adam Smith mentions these in his book. The Dutch East India Company also produced the first governance scandal. Other sources state that the University was the first corporation established in 1088 [4].

The "Parable of the Talents", in Matthew 25:14-30, also represented the principal-agent principle. The master trusts three servants with bags of gold and goes on a journey. When he returns he expects that these servants will have put the money to work and he judges them based on their earnings.

In 2004 Bakan (2016) [5] blew our minds away with his book "The Corporation; The Pathological Pursuit of Profit and Power". He stated that a corporation is an institution and a legal construction. According to Bakan, by nature the corporation is programmed to pursue profit in a pathological manner. The only value the corporation knows is money/profit, at any 
cost; nature and human lives are less important. Corporations have no ethics. That is why corporations must be governed.

Corporate governance is about the way power is exercised over corporate entities. It covers the activities of the board and its relationships with the stakeholders or members, and with those managing the enterprise, as well as the external auditors, regulators and other legitimate stakeholders. It is different from management. Management runs the company but the governing board ensures it is run well in the right direction [6].

The aim of good governance is to induce the organization to behave as ethically as possible. Good governance is governing according to the following principles:

- Honesty

- Transparency

- Accountability

- Responsiveness

- Independence

- Fairness

Over the years, I have noticed that the concept of governance is confusing. Governance is an act of steering - the steering of organizations. There are three main areas or domains of governance (Figure 1): public governance, corporate governance, and NGO governance. These three domains are characterized by their primary governance mechanism: hierarchy (authority), network (trust) and market (competition) governance [7].These three areas have three levels or scales of governance: local and regional (small), national (medium), and transnational (large). Each domain and scale has its own characteristics, which can become more complicated because there are hybrids. For example, the state-owned company is a hybrid since it operates in the domains of corporate governance, but also in the domain of public governance.

\begin{tabular}{|c|c|c|c|}
\hline & \multicolumn{3}{|l|}{ Governance } \\
\hline & Pubic & NGO & Corporate \\
\hline & Hierarchy - authority & Network - trust & Market - competition \\
\hline Micro & & & \\
\hline Mezzo & & & \\
\hline Macro & & & \\
\hline
\end{tabular}

Figure 1: The domains of governance

Corporations can be ranked on a scale from micro to global corporations. All have a form of governance. This from varies depending on the scale, the industry and the culture. For example, the shareholders are much more involved in the small and medium enterprise, compared to the big corporation, but they also benefit from involving outsiders [8].

Corporate governance has an internal and an external dimension and has a short term and a long term track. It is all about: Supervision, Steering, Control and Accountability. 


\begin{tabular}{|l|l|l|}
\hline External & Long Term & Short Term \\
\hline & $\begin{array}{l}\text { Supervision } \\
\text { Supervisory board } \\
\text { Shareholders meeting }\end{array}$ & $\begin{array}{l}\text { Accountability } \\
\text { Annual report } \\
\text { Annual financial report } \\
\text { Declaration of the } \\
\text { accountant } \\
\text { Monthly, quarterly and } \\
\text { Internal }\end{array}$ \\
\hline $\begin{array}{l}\text { Stearly reports } \\
\text { Strategic plan } \\
\text { Organization } \\
\text { development plan } \\
\text { Plan and control cycle } \\
\text { Multi-annual budget }\end{array}$ & $\begin{array}{l}\text { Control } \\
\text { Progress reports } \\
\text { Business plans and } \\
\text { budgets } \\
\text { Quarterly management } \\
\text { Conferences twice a }\end{array}$ \\
\hline
\end{tabular}

Figure 2: Corporate Governance [9]

So there is not one model of corporate governance. Onofrei (2007) identifies three main models of corporate governance: The Traditional model, Co-determination model, and Stakeholder model. [10]

The North American system is the basis of the traditional model. It acknowledges three levels of hierarchy: shareholders, directors and managers. The power of the manager stems from the authority of the directors.

The Western European countries, especially Germany, created the co-determination model. The German economy is based on co-determination, meaning that different social categories attempt to raise social welfare [11]. The difference from the traditional model is that this model presents a participatory system of management.

The Southeast Asian states created a third model also characterized by four hierarchical levels. The difference from the European model of co-determination is in the form of the complex relationships. In this model all stakeholders have weight but the scope of rights and obligations is somewhat unclear. This somehow explains the balance between descion-making processes and the corresponding level where this takes place [12].

Corporate governance models are primarily geared toward large companies, but they can also be applied to smaller organizations [13].

Another qualification of corporate governance models is the dichotomy between one-tier and two-tier boards. The one-tier board is the Anglo-Saxon model in which some members of the supervisory board are also members of the executive board. The two-tier board is the continental model that strictly separates the two functions.

\section{PRINCIPAL AGENT THEORY}

Principal agent theory states that the agent (management) will pursue its self-interest and not the best interest of the principal (shareholders). To prevent this from happening, corporate governance structures are created. The owner or shareholders appoint the board to supervise management. This is an asymmetric relationship as management has far more information 
about the company than the supervisory board and shareholders.

The objective of corporate governance is to structure the principal agent relationship and to control the corporation and make it behave to serve the objectives of the corporation, the shareholders and other stakeholders. Mintzberg proposed several constellations for controlling big business, that is, the corporation. These proposals are illustrated in graphical form by a "conceptual horseshoe" and each position represents a different view of who controls the corporation.

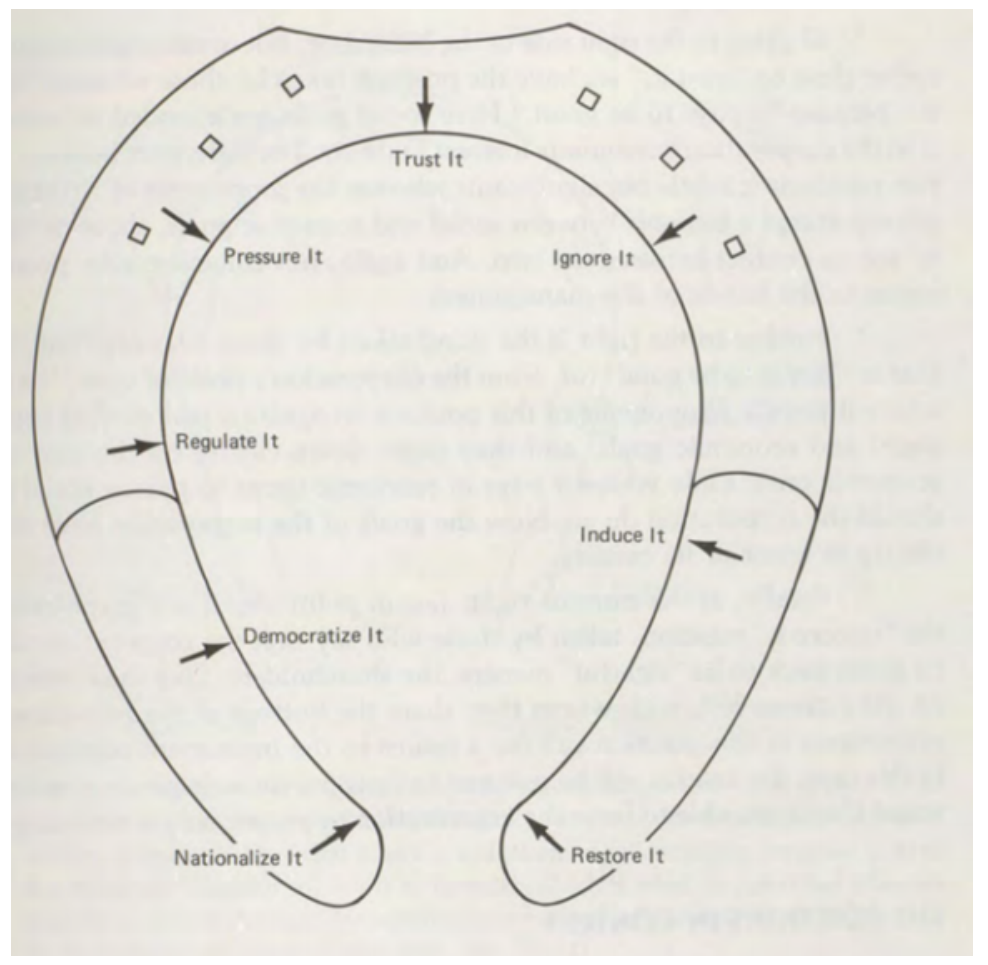

Figure 3: The exceptional horse shoe [14]

In short, the positions are:

1. Nationalize It: The government nationalizes the corporation and controls its behavior.

2. Democratize It: The goals of the corporation are expanded by changing the power basis, allowing various groups to participate and influence management.

3. Regulate It: The government actively and formally prescribes what the corporation does.

4. Pressure it: Special interest groups and others bring about change through pressure campaigns.

5. Trust It: Management consider it their moral duty to seek a moral balance between economic and social goals. In the balance of power, power remains with management because they act responsibly.

6. Ignore It: It is in the corporation's economic interest to pursue social goals, because it pays to be good.

7. Induce It: Management is aware of the conflict between economic and social goals, but the economic goals get the upper hand. The social goals are only served if it pays in economic terms to pursue them. In other words society has to pay the corporation for social goals to be looked after.

8. Restore It: The shareholder, the rightful owner of the corporation, controls the corporation and is only interested in economic goals [15]. 
The problem with these propositions of Mintzberg is that he assumes the government or state is neutral. There are strong indications that the influence of corporations on government are significant [16]. Some observers argue that corporations rule the world [17].

\section{NEOLIBERALISM}

The rise of corporate governance is related to neoliberalism. Neoliberalism is the ideology of the market and thus of the corporations. The dissemination of this ideology across the globe is described as "the Washington consensus", because it was pushed by institutions like the IMF and the World Bank that are based in Washington. When, in the 1970s and 1980s, the ideology became dominant, we saw a shift of production of services and goods from the public and NGO domains to the market domain. For example, education and healthcare became industries.

The dominance of the corporation occurred in this period, when, under neoliberalism, the corporation eroded all values in society and only one strong value remained: money and wealth. Some argue that neoliberalism is the ideology at the root of all our problems [18]. Neoliberalism has brought out the worst in us $[19,20]$.

Margaret Thatcher once stated in an interview with the Sunday Times: "Economics are the method, but the object is to change the soul". And what kind of soul was it Thatcher wanted us to have? One based upon materialistic individualism and a self-interested outlook, of course. If we want to understand why conditions are now ripe for fraud across all capitalist countries and across all levels of society, we must recognise that it is not because of the lack of soul or the absence of morals, but because at the heart of the neo-liberal project there exists a very clear set of norms, values and attitudes that have been actively encouraged, that we voted for, and which now we find so hard to rationalise or understand [21].

This new soul is exposed by the Paradise Papers and other papers. The leak of the Paradise Papers released 13.4 million confidential papers from one office in Panama to the press, and gave an insight into how the wealthy hide their money in tax loopholes. The Papers illustrate greed and corruption, particularly of the elite [22]. In 2017 the richest 1\% of people earned $82 \%$ of all the wealth produced [23]. The new soul has led to problems like global warming and climate change [24].

One might wonder how countries that were governed by socialists also got into trouble if neoliberalism is the root cause. In countries like Venezuela and Brazil the socialists came to power because the neoliberals failed to improve the situation of the poor masses. This created fertile ground for the populist left. Once in power they exhibited the same greed in the form of corruption. The constant factors seem to be greed, money and corruption, leading to bad governance. Often these rulers were corrupted by corporations, like Petrobras [25, 26] and Odebrecht [27].

\section{EMERGENCE OF THE GOOD CORPORATE GOVERNANCE CODE}

Good Corporate Governance Codes were a reaction to correct the excesses that let to scandals like Enron and WorldCom. However, In 2006 In 't Veld [28] stated that governance codes amputate values and replace them with a prosthesis. In other words good governance codes eliminate precisely what they try to protect and promote; values and virtues. People no longer behave based on virtues but just comply with the rules of the code.

For a while there were further attempts to temper this tendency to move away from values and virtues by introducing the concept of the triple bottom line: people, planet, profit [29]. This concept entails the balancing of the interests of people, the environment and shareholders. 
Another attempt to correct the corporation was the introduction of the balanced score card, balancing the scope of profit or finance with scores related to customers, internal business processes and learning and growing [30].

- Financial: it is about identifying a few high-level relevant financial indicators. It is about answering the question: "How does the shareholder perceive the company?" It is about cash flow, growth of sales, operating income, and return on equity.

- Customer: the indicators that help to answer the question, "What is important to the costumer and other stakeholders?" For example: market share, on time performance, ranking of important costumers.

- Internal business processes: the indicators help to answer the question, "What must we improve to excel?" Examples are: unit cost, cycle time.

- Learning and growth: the indicators must assist in answering the question, "How do we continue to improve, create value and innovate?" Examples are time to develop a new product, time to the market.

Another concept was coined: CRS or Corporate Social Responsibility:

Corporate Social Responsibility (CSR) is about how companies manage the business processes to produce an overall positive impact on society. Thus companies consider the interests of society by taking responsibility for the impact of their activities on customers, suppliers, employees, shareholders, communities and other stakeholders, as well as on the environment. This is seen to extend beyond the statutory obligation to comply with legislation as organizations voluntarily take further steps to improve the quality of life for employees and their families as well as for the local community and society at large. If a company chooses to follow the way of CSR, it will integrate ethical concerns in its activities and its interaction with all the stakeholders [31].

Corporate governance seems to be a pre-condition for CSR [32].

These were all attempts to temper the ferocious pursuit of profit by corporations. The results are not encouraging. The attempts look like window-dressing and some people wonder if capitalism is broken.

Some predict that the end of capitalism as we know it has begun. "Without us noticing, we are entering the post capitalist era. At the heart of further change to come is information technology, new ways of working and the sharing economy. The old ways will take a long while to disappear, but it's time to be utopian" [33]. Capitalism is broken with no way of fixing it [33]. Futurists are seeking an alternative without money [34].

The sharing economy is the collective consuming by individuals by using the internet. Examples of this are Uber to get a taxi and Airb\&b to rent a room $[35,36]$.

\section{THE CORPORATE GOVERNANCE CYCLE}

The 'yin' and 'yang' of the capitalist system are widely known. On the positive side, capitalism is associated with wealth production, economic prosperity and corporate success. On the negative side, capitalism is associated with greed, despotism, abuse of power, opacity, social inequality and unfair distribution of wealth [37].

The normal model of capitalism is that we think about progress in a linear way. This rational/logical model is the thesis proposed by neoliberalism. The alternative, circular way of thought can be seen as the antithesis presented by some traditional ethical models (Figure 4) 
[38]. The thesis is devoted more to short-term than long-term thinking. I propose an antithesis in which corporate governance is perceived as a circular, long term process of value creation, rather than as a linear, short-term profit seeking process.

\begin{tabular}{|l|l|}
\hline Thesis & Antithesis \\
\hline Outside-in & Inside-out \\
\hline Linear & Circular \\
\hline Short-term & Long-term \\
\hline Individualistic & Collective \\
\hline
\end{tabular}

Figure 4: Thesis regarding corporate governance and its Antithesis

A corporate governance code is an outside-in approach. It does not build on, nor appeal to virtues of the individual, organization and society. People just comply with what is written in the code, or they do not. What is an inside-out approach?

Kautilya Arthasastra presents a short inside-out approach to CRS [39]. It is the development of an individual leader's self-consciousness, as opposed to the western perspective that takes an outside-in approach. Leaders in corporations are crucial in ensuring transparency, good behavior and governance steering towards the ultimate objective of CSR [40].

Figure 5 was created by Bossert and is an expression of linear thinking.

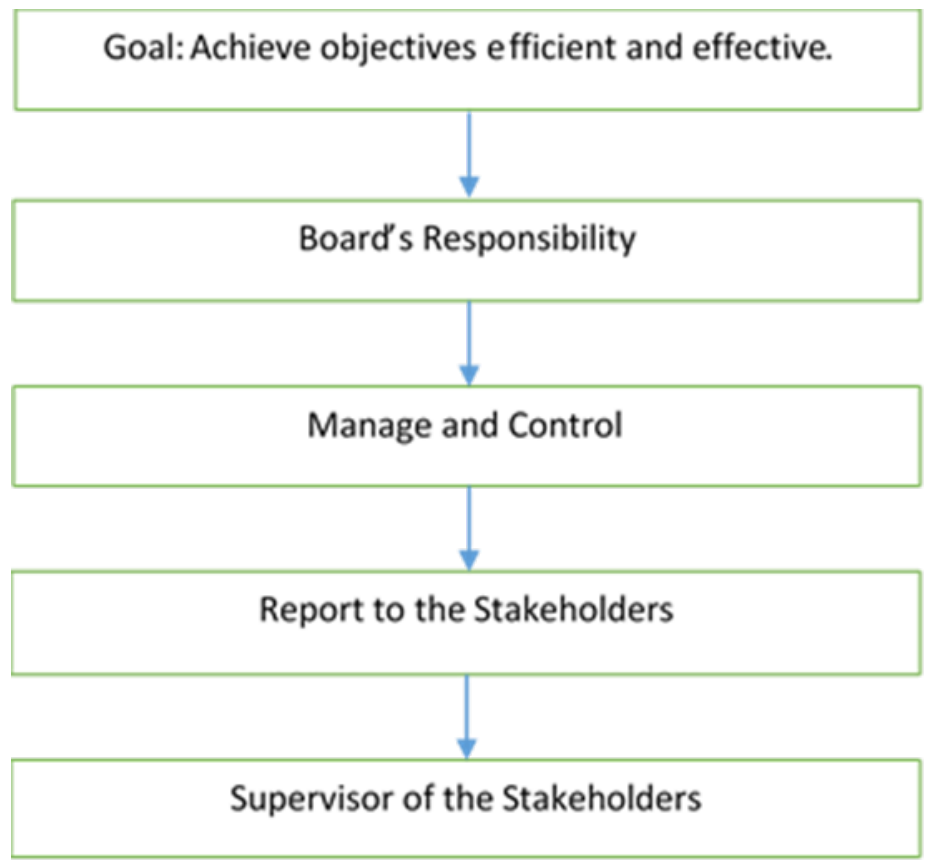

Figure 5: Government Process Bossert

The antithesis is more circular. Was it coincidence that Deming introduced his PDCA cycle in 1950 in Japan? Moen et al. claim that the PDCA cycle is not a specifically eastern philosophy [41]. They rightly state that the philosophy of the PDCA cycle can be applied on all levels of an organization, and all levels of governance of the organization (Figure 6). 

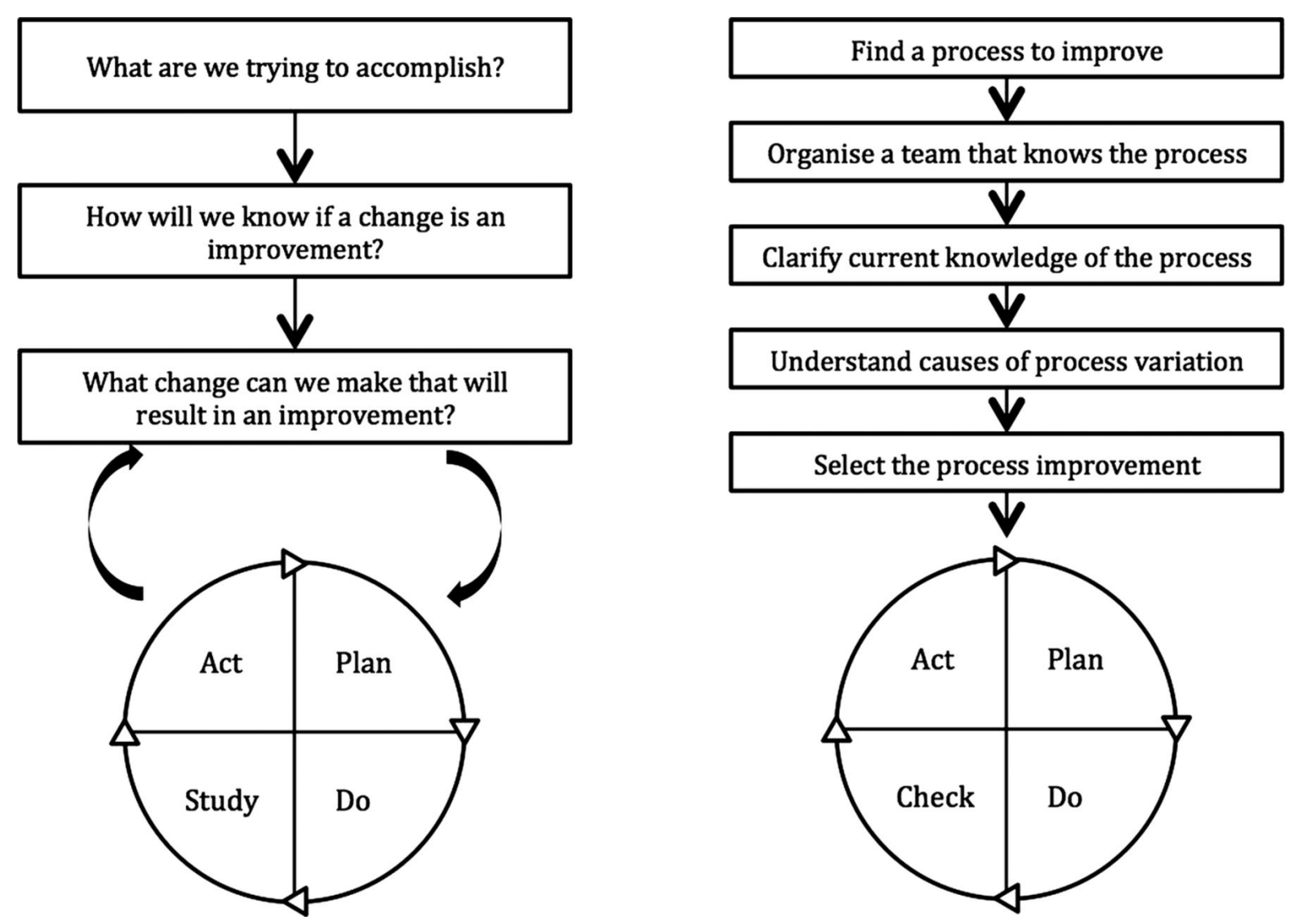

Figure 6: The Model for Improvement: FOCUS [42]

Kaizen is the Japanese philosophy of continuous improvement [43].

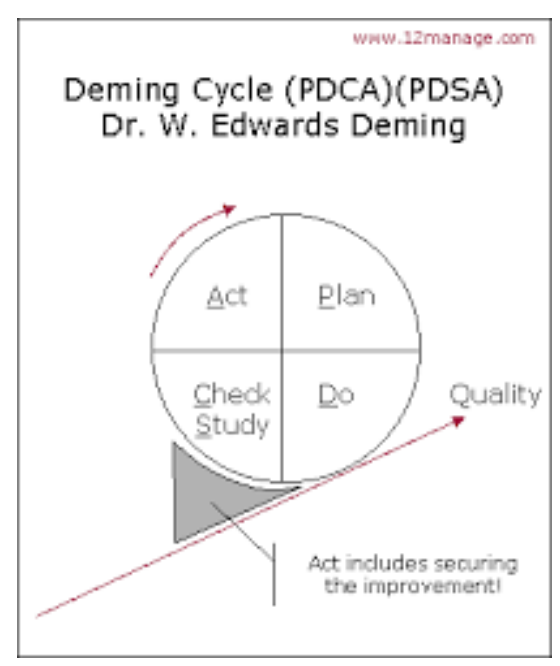

Figure 7: The Deming Cycle [44]

The Deming cycle can also illustrate that corporate governance is a circular process of continuous improvement towards better governance by improving and securing progress (Figure 7). The rising line illustrates growth and progress. The circle illustrates the dynamic circular movement of the governance process. The triangle illustrates the securing of progress already made. 
In the current dominant paradigm of corporate governance, business is often about becoming big fast. The shareholder is focused on fast return on investment. There is an emphasis on the quarterly report.

\section{CONVERTING LINEAR INTO CIRCULAR}

I propose the conversion of the dichotomy into a corporate governance cycle. Corporate governance steers these cycles of the corporation based on the PDCA or Deming cycle approach to the next level.

\begin{tabular}{|l|l|l|}
\hline & Long Term & Short Term \\
\hline External & Supervision & \\
\hline Internal & & \\
\hline
\end{tabular}

Figure 8: The -Supervision- Steering - Control - Accountability- Corporate Governance Cycle [45]

The most noticeable cycle is the annual cycle starting with the annual budget and ending with the financial year report, audited by the external accountant. The next noticeable cycle of corporate governance is the quarterly cycle, which ends with the quarterly report presented by corporations. This is an illustration of our short-term focus, because it is part of the annual cycle which ends with the approval by the shareholders of the annual report, audited by the external accountant. There are shorter cycles: the monthly, weekly and daily cycles. Strategic planning and vision are also very important and are long term cycles.

The essence of a cycle is that everything repeats. The organization can evaluate the past and make adjustments. The organization and all involved can learn.

The objective of good corporate governance should be to keep the cycles turning, creating sustainable development, producing a meaningful output, reducing the impact on the earth to a minimum, and creating meaningful jobs [46]. It is about the doughnut economy [47, 48]. 


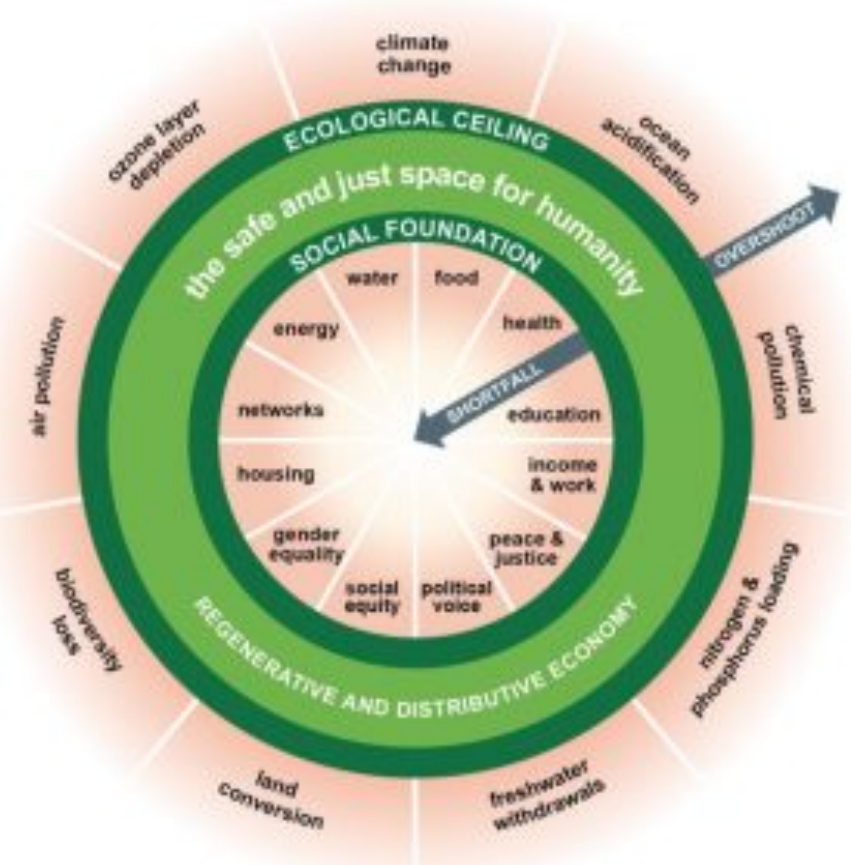

Figure 9: The Doughnut of social and planetary boundaries [49]

It is a coincidence that the doughnut is a circle (Figure 9). In her doughnut model, Raworth points to a sweet-spot between meeting human needs and living within the means of the planet. This model sets an environmental limit (consisting of nine planetary boundaries and twelve dimensions of social foundations), derived from internationally agreed minimum social standards.

The main cycle is the vision and mission cycle, because this is where the corporation establishes its raison d'être. Making money is not an objective but a condition for continuity in order to realize the objective. A corporation's raison d'être is to pursue a value, to solve a social problem.

"Society is demanding that companies, both public and private, serve a social purpose... To prosper over time, every company must not only deliver financial performance, but also show how it makes a positive contribution to society. Companies must benefit all of their stakeholders, including shareholders, employees, customers, and the communities in which they operate" [50].

To reach its objective the company strives for continuity and hence a profit to reinvest and reward shareholders. To pursue its goals, the corporation has a vision that it follows by implementing a plan, broken-down into annual plans. Governance is about steering the corporation, and executing the vision and the plan. It is about action to reach noble objectives. And it is about reflecting how matters should be adjusted along the way.

\section{References}

Tricker, R. B., \& Tricker, R. I. (2015). Corporate governance: Principles, policies, and practices. Oxford University Press, USA.

Kennedy, G. (2009). Adam Smith's Lost Legacy: On Smith's Approach to Corporate Governance. Adamsmithslostlegacy.blogspot.com. Retrieved 3 January 2018, from https://adamsmithslostlegacy.blogspot.com/2009/10/on-smiths-approach-to-corporate.html 
Bakan, J. (2016). The corporation as a pathological. The Political Self: Understanding the Social Context for Mental Illness, 173.

Holborn Gray, H. (2018).The University in History: 1088 And All That. Iotu.uchicago.edu. Retrieved 29 January 2018, from http://iotu.uchicago.edu/gray.html

Bakan, J. (2016). The corporation as a pathological. The Political Self: Understanding the Social Context for Mental Illness, 173.

Tricker, R. B., \& Tricker, R. I. (2015). Corporate governance: Principles, policies, and practices. Oxford University Press, USA.

Meuleman, L. (2010). The cultural dimension of metagovernance: why governance doctrines may fail. Public Organization Review, 10(1), 49-70.

Brunninge, O., Nordqvist, M., \& Wiklund, J. (2007). Corporate governance and strategic change in SMEs: The effects of ownership, board composition and top management teams. Small Business Economics, 29(3), 295-308.

Primonederland.eu. Retrieved 9 January 2018, from https://primonederland.eu/wp-

content/uploads/2002/09/bossert-good-gevernance-de-leidraad-voor-goed-bestuur-en-management-artn.68.pdf

Onofrei, M. (2007). Management financiar. CH Beck.

Brezeanu, P., \& Stănculescu, A. (2008). Corporate governance models.VOL. VIII PART I, 15.

Mintzberg, H. (1984). Who should control the corporation?. California Management Review, 27(1), 90-115.

Bakan, J. (2016). The corporation as a pathological. The Political Self: Understanding the Social Context for Mental Illness, 173.

Korten, D. C. (1998). When corporations rule the world. European Business Review, 98(1).

Monbiot, G. (2016). Neoliberalism - the ideology at the root of all our problems. the Guardian. Retrieved 8 January 2018, from https://www.theguardian.com/books/2016/apr/15/neoliberalism-ideology-problem-georgemonbiot?CMP=fb_gu

Verhaeghe, P. (2014). Neoliberalism has brought out the worst in us | Paul Verhaeghe. the Guardian. Retrieved 8 January 2018, from https://www.theguardian.com/commentisfree/2014/sep/29/neoliberalism-economicsystem-ethics-personality-psychopathicsthic

Joseph Stiglitz on rewriting the rules of the market economy. (2018). YouTube. Retrieved 17 January 2018, from https://www.youtube.com/watch?v=ZyKkmzgge90

Wiegratz, J., \& Whyte, D. (2018). How neoliberalism's moral order feeds fraud and corruption. The Conversation. Retrieved 8 January 2018, from https://theconversation.com/how-neoliberalisms-moral-order-feeds-fraud-andcorruption-60946

Gansky, L. (2010). The mesh: Why the future of business is sharing. Penguin. Garside, J. (2017). Paradise Papers leak reveals secrets of the world elite's hidden wealth. the Guardian. Retrieved 8 January 2018, from https://www.theguardian.com/news/2017/nov/05/paradise-papers-leak-reveals-secrets-of-world-eliteshidden-wealth?CMP=fb_gu

Kottasová, I. (2018). World's richest $1 \%$ grabbed $82 \%$ of all wealth created in 2017 , Oxfam study finds. CNNMoney. Retrieved 22 January 2018, from http://money.cnn.com/2018/01/21/news/economy/davos-oxfaminequality-wealth/index.html

Watts, J. (2017). From Miami to Shanghai: 3C of warming will leave world cities below sea level. the Guardian. Retrieved 8 January 2018, from https://www.theguardian.com/cities/2017/nov/03/miami-shanghai-3cwarming-cities-underwater?CMP=fb_gu

Brazil politicians linked to Petrobras scandal draft bills for 'self-preservation'. (2016). the Guardian. Retrieved 8 January 2018, from https://www.theguardian.com/world/2016/nov/11/brazil-petrobras-corruption-scandalpoliticians-bills

Phillips, D. (2017). Brazil's right on the rise as anger grows over scandal and corruption. the Guardian. Retrieved 8 January 2018, from https://www.theguardian.com/world/2017/jul/26/brazil-rightwing-dilma-rousseff-lula

Pegg, D. (2017). Corrupt Brazilian tycoon among applicants for Portugal's golden visas. the Guardian. Retrieved 8 January 2018, from https://www.theguardian.com/world/2017/sep/18/portugal-golden-visas-corruptbrazilian-tycoon-among-applicants 
in 't Veld, R., Governance als prothese voor deugdzaamheid, Universiteit van de Nederlandse Antillen, Curaçao, 16 maart 2006 (oratie).

Line, T. B. (2009). Triple Bottom Line. Retrieved, 4(09), 2015.

Jensen, M. C. (2001). Value maximization, stakeholder theory, and the corporate objective function. Journal of applied corporate finance, 14(3), 8-21.

Luc, J. (2018). Corporate social responsibility.

Jamali, D., Safieddine, A. M., \& Rabbath, M. (2008). Corporate governance and corporate social responsibility synergies and interrelationships. Corporate Governance: An International Review, 16(5), 443-459.

Mason, P. (2015). The end of capitalism has begun. the Guardian. Retrieved 8 January 2018, from https://www.theguardian.com/books/2015/jul/17/postcapitalism-end-of-capitalism-begun

NowThis Future. (2018). Facebook.com. Retrieved 22 January 2018, from https://www.facebook.com/NowThisFuture/videos/1500983249942850/?notif_id=1516658863235194\&notif_t $=$ mention

Gansky, L. (2010). The mesh: Why the future of business is sharing. Penguin. Garside, J. (2017).

Silver, J. (2013). The sharing economy: a whole new way of living. the Guardian. Retrieved 12 January 2018, from https://www.theguardian.com/technology/2013/aug/04/internet-technology-fon-taskrabbit-blablacar

Solomon, J. (2007). Corporate governance and accountability. John Wiley \& Sons.

Kim, D. H. (2003). Oriental way of systems thinking. 한국시스템다이내믹스 연구, 4(1), 55-68.

Dgcoach.nl. Retrieved 9 January 2018, from http://dgcoach.nl/wp-content/uploads/2016/10/GoodGovernance.pdf

Muniapan, B., \& Dass, M. (2008). Corporate social responsibility: A philosophical approach from an ancient Indian perspective. International Journal of Indian Culture and Business Management, 1(4), 408-420.

Moen, R., \& Norman, C. (2006). Evolution of the PDCA cycle.

Taylor, M., McNicholas, C., Nicolay, C., Darzi, A., Bell, D., \& Reed, J. (2013). Systematic review of the application of the plan-do-study-act method to improve quality in healthcare. BMJ Quality \& Safety, 23(4), 290-298. doi:10.1136/bmjqs-2013-001862

Karkoszka, T., \& Honorowicz, J. (2009). Kaizen philosophy a manner of continuous improvement of processes and products. Journal of Achievements in Materials and Manufacturing Engineering, 35(2), 197-203.

B.V., (2018). PDCA PDSA Deming Cycle - Knowledge Center. 12manage.com. Retrieved 10 January 2018, from https://www.12manage.com/methods_demingcycle.html

Primonederland.eu. Retrieved 9 January 2018, from https://primonederland.eu/wp-

content/uploads/2002/09/bossert-good-gevernance-de-leidraad-voor-goed-bestuur-en-management-artn.68.pdf

Goede, M. (2017). Education in a World Where There Are Not Enough Jobs.

Raworth, K. (2017). Doughnut Economics: Seven Ways to Think Like a 21st-Century Economist. Chelsea Green Publishing.

Toye, R. (2018). Doughnut Economics by Kate Raworth review - forget growth, think survival. [online] the Guardian. Available at: https://www.theguardian.com/books/2017/jun/08/doughnut-economics-by-kateraworth-review [Accessed 11 Jan. 2018].

Raworth, K. (2018). Meet the doughnut: the new economic model that could help end inequality. [online] World Economic Forum. Available at: https://www.weforum.org/agenda/2017/04/the-new-economic-model-thatcould-end-inequality-doughnut/ [Accessed 11 Jan. 2018].

Larry Fink, j. (2018). Larry Fink, CEO of $\$ 6.3$ trillion manager BlackRock, just sent a warning letter to CEOs everywhere. Business Insider. Retrieved 17 January 2018, from http://www.businessinsider.com/blackrock-ceolarry-fink-just-sent-a-warning-to-ceos-everywhere-2018-

1?utm_content=bufferc7341\&utm_medium=social\&utm_source=facebook.com\&utm_campaign=buffer-ti 